\title{
EFFECT OF GLYCOSIDASE INHIBITORS ON THE CAPACITATION OF HAMSTER SPERMATOZOA BY CUMULUS CELLS IN VITRO
}

\author{
R. B. L. GWATKIN AND O. F. ANDERSEN \\ Merck Institute for Therapeutic Research, Rahway, New Jersey, U.S.A.
}

(Received 17th Fuly 1973)

Rapid transport of spermatozoa to the site of fertilization in the oviduct has been demonstrated in several species (Howe \& Black, 1963; Yanagimachi \& Chang, 1963; Harper, 1973). In the mouse, the uterotubal junction was shown to close a few minutes after mating (Zamboni, 1972). These findings suggest that, at least in some species, normal physiological capacitation of the spermatozoa takes place in the oviduct rather than in the uterus. Using hamster gametes in vitro, we earlier demonstrated that the cumulus oophorus and not the oviducal fluid is responsible for the capacitating action of the postovulatory contents of the oviduct (Gwatkin, Andersen \& Hutchison, 1972).

When hamster spermatozoa are incubated with cumulus cells in vitro, the spermatozoa bind to a neuraminidase-sensitive site on the cell surface and detach spontaneously 3 to $4 \mathrm{hr}$ later (Gwatkin $e t$ al., 1972). In the presence of a dialysable factor from the cumulus matrix, spermatozoa are produced which are capable of binding to a trypsin-sensitive receptor on the zona pellucida (Hartmann \& Gwatkin, 1971) and of entering eggs (Gwatkin et al., 1972).

Since our earlier studies provided evidence for the existence of conjugated glucuronides on the surface of hamster spermatozoa (Gwatkin \& Hutchison, 1971), the possible rôle of glycosidases which split these mucopolysaccharides was explored with enzyme inhibitors. Various concentrations of glucaro $(1 \rightarrow 4)$ lactone $(\mathrm{GL})$, a specific inhibitor of $\beta$-glucuronidase structually related to the sugar moiety in its substrate (Levvy, 1952) were prepared in TC medium 199 (Morgan, Morton \& Parker, 1950), modified to contain $30 \mu$ g sodium pyruvate $/ \mathrm{ml}, 3 \mathrm{mg}$ crystalline bovine plasma albumin $/ \mathrm{ml}$ and $2 \mathrm{mg}$ sodium bicarbonate $/ \mathrm{ml}$. This medium was designated 199M2. Aliquots $(10 \mu l)$ of these solutions were mixed in droplets under mineral oil with an equal volume of cumulus cells $\left(2 \times 10^{5} / \mathrm{ml}\right)$ dispersed in solubilized matrix. This was prepared by placing the cumulus clots formed by twenty to thirty eggs in $100 \mu \mathrm{l}$ hyaluronidase solution (450 U.S.P. units/ml Dulbecco's phosphate-buffered saline, $\mathrm{pH} 7 \cdot 2$ ), counting the dispersed cells by haemocytometers and then diluting to the appropriate cell concentration. Epididymal sperm suspension ( $20 \mu \mathrm{l}$ containing $10^{7}$ motile spermatozoa $/ \mathrm{ml}$ ) were added to the droplets and the cultures were incubated on a rocker (five to six oscillations $/ \mathrm{min}$ ) at $37^{\circ} \mathrm{C}$ under $5 \% \mathrm{CO}_{2}$ in air for $5 \mathrm{hr}$. Cumulus-free eggs were then added and sperm penetration into the eggs was scored 90 min later, as previously described (Gwatkin et al., 1972). 
Table 1 shows that GL in concentrations as low as $2 \mu \mathrm{g} / \mathrm{ml}$ completely inhibited capacitation by the frozen-thawed cells. Inhibition of capacitation by the intact cells, however, required an inhibitor concentration which was more than fifty times greater. The results suggest that $\beta$-glucuronidase is involved in the capacitating action of the cumulus oophorus and that the enzyme acts where it is relatively inaccessable to the inhibitor, probably while the sperm-

Table 1. Effect of glucaro $(1 \rightarrow 4)$ lactone (purchased from Calbiochem. Corp.) on hamster sperm capacitation by cumulus before and after disruption of the cells by freezing and thawing

\begin{tabular}{c|cc|cc}
\hline & \multicolumn{3}{|c}{ No. of ova ${ }^{*}$ penetrated by spermatozoa } \\
\cline { 2 - 5 } $\begin{array}{c}\text { Inhibitor } \\
(\mu g / m l)\end{array}$ & $\begin{array}{r}\text { Frozen and thawed cumulus cells } \\
\text { Exp. I }\end{array}$ & Exp. 2 & \multicolumn{2}{|c}{ Extact cumulus cells } \\
\cline { 2 - 5 } & 10 & 11 & 15 & 15 \\
2 & 0 & 0 & & \\
20 & 0 & 0 & 15 & 11 \\
100 & & & 12 & 7 \\
1000 & & & $0 \dagger$ & $0 \dagger$ \\
\hline
\end{tabular}

* Number of ova out of a total of twenty ova.

† Glucose $(2 \mathrm{mg} / \mathrm{ml})$ did not affect capacitation, hence action of inhibitor at high concentration is not attributable to such non-specific effects as increased osmolarity.

Table 2. Effect of inhibitors of $\mathrm{N}$-acetylglucosaminidase and hyaluronidase on hamster sperm capacitation in vitro

\begin{tabular}{|c|c|c|c|c|c|}
\hline \multirow{3}{*}{ Inhibitor } & \multirow{3}{*}{$\begin{array}{c}\text { Concentration } \\
(\mu \mathrm{g} / \mathrm{ml})\end{array}$} & \multicolumn{4}{|c|}{ No. of ova* penetrated by spermatozoa } \\
\hline & & \multicolumn{2}{|c|}{ Frozen and thawed cumulus cells } & \multicolumn{2}{|c|}{ Intact cumulus cells } \\
\hline & & $\begin{array}{l}5 \times 10^{5} \\
\text { cells } / \mathrm{ml}\end{array}$ & $\begin{array}{c}10^{6} \\
\text { cells } / \mathrm{ml}\end{array}$ & $\begin{array}{l}5 \times 10^{5} \\
\text { cells } / \mathrm{ml}\end{array}$ & $\begin{array}{c}10^{6} \\
\text { cells } / m l\end{array}$ \\
\hline None & - & 3 & 4 & 10 & 10 \\
\hline ADGL & $\begin{array}{r}3 \\
10 \\
30 \\
100\end{array}$ & $\begin{array}{l}2 \\
0 \\
0 \\
0\end{array}$ & $\begin{array}{l}4 \\
3 \\
0 \\
0\end{array}$ & $\begin{array}{l}9 \\
8 \\
3 \\
1\end{array}$ & $\begin{array}{l}9 \\
7 \\
4 \\
3\end{array}$ \\
\hline AATC & $\begin{array}{r}10 \\
30 \\
300\end{array}$ & $\begin{array}{l}4 \\
5 \\
0\end{array}$ & $\begin{array}{l}4 \\
5 \\
0\end{array}$ & $\begin{array}{l}3 \\
1 \\
0\end{array}$ & $\begin{array}{l}8 \\
6 \\
0\end{array}$ \\
\hline
\end{tabular}

ADGL = 2-Acetamido-2-deoxygluconolactone (Koch-Light Labs.).

AATC $=$ Ammonium aurin tricarboxylate ( $K$ \& $K$ Labs. $)$.

* Number of ova out of a total of ten ova.

atozoa are bound to the cells. These results are in agreement with our previous report that GL at $5 \mu \mathrm{g} / \mathrm{ml}$ blocks capacitation by crude $\beta$-glucuronidase solutions but does affect capacitation by the cumulus oophorus in vitro (Gwatkin \& Hutchison, 1971).

Glucuronides, such as hyaluronic acid and chondroitin sulphate, are not attacked by purified $\beta$-glucuronidase since this enzyme cleaves only terminal 
glucuronic acid groups (Levvy \& Conchie, 1966). Complete hydrolysis of hyaluronic acid is believed to require the sequential action of two more glycosidases, $\beta$-N-acetylglucosaminidase and hyaluronidase. Table 2 presents the results of experiments similar to those already described, but using 2acetamido-2-deoxygluconolactone (ADGL), a specific competitive inhibitor of $\beta$-N-acetylglucosaminidase, and ammonium aurintricarboxylate (AATC), a relatively unspecific inhibitor of hyaluronidase which acts by competing for the polycationic activators of this enzyme (Mathews \& Dorfman, 1955). At a cell concentration of $5 \times 10^{5} / \mathrm{ml}$, ADGL completely inhibited capacitation by the frozen and thawed cells at a concentration of $10 \mu \mathrm{g} / \mathrm{ml}$. With the intact cells, capacitation was inhibited but the inhibition was not complete, even at 100 $\mu \mathrm{g} / \mathrm{ml}$. A similar difference between frozen and thawed cells was observed at a cell concentration of $10^{6} / \mathrm{ml}$. These results suggest that $\beta-\mathrm{N}$-acetyl-glucosaminidase is involved in cumulus cell-induced capacitation and that, like $\beta$-glucuronidase, it may act on the spermatozoa when they are bound to the cumulus cells. In contrast to these inhibitors, AATC was about equally effective in inhibiting capacitation by the frozen-thawed and intact cells, suggesting that, if hyaluronidase is involved, it acts in solution where it would be accessible to the inhibitor.

The high degree of enzyme specificity exhibited by the lactones, which derives from their close structural relationship to the respective sugars in their substrates, provides strong evidence that capacitation by the cumulus oophorus involves the glycosidases, $\beta$-glucuronidase and $\beta$ - $\mathrm{N}$-acetylglucosaminidase. The differential response of the frozen-thawed cells and intact cells suggests that these enzymes may act on the spermatozoa while they are bound to the cumulus cells. The nature of this association is currently being explored both in vivo and in vitro by transmission and scanning electron microscopy to determine whether the spermatozoa fuse with the cell surface in such a way as to allow lysosomal enzymes to act on the plasma membrane of the sperm head.

\section{REFERENCES}

Gwatkin, R. B. L., Andersen, O. F. \& Hurchison, G. F. (1972) Capacitation of hamster spermatozoa in vitro: the rôle of cumulus components. F. Reprod. Fert. 30, 389.

Gwatkin, R. B. L. \& Hutchison, G. F. (1971) Capacitation of sperm by $\beta$-glucuronidase. Nature, Lond. 229, 343.

HARPER, M. J. K. (1973) Stimulation of sperm movement from the isthmus to the site of fertilization in the rabbit oviduct. Biol. Reprod. 8, 369.

Hartmann, J. F. \& Gwatkin, R. B. L. (1971) Alteration of sites on the mammalian sperm surface following capacitation. Nature, Lond. 234, 479.

Howe, G. R. \& BLACK, D. L. (1963) Spermatozoan transport and leucocyte responses in the reproductive tract of calves. F. Reprod. Fert. 6, 305.

Levvy, G. A. (1952) The preparation and properties of $\beta$-glucoronidase. 4. Inhibition by sugar acids and their lactones. Biochem. F. 52, 464.

LEvvy, G. A. \& Conchie, J. (1966) $\beta$-Glucuronidase and the hydrolysis of glucuronides. Glucuronic Acid, Free and Combined, Gh. 4. Ed. G. J. Dutton. Academic Press, London.

Mathews, M. D. \& Dorfman, A. (1955) Inhibition of hyaluronidase. Physiol. Rev. 35, 381.

Morgan, J. F., Morton, H. J. \& Parker, R. G. (1950) Nutrition of animal cells in tissue culture. I. Initial studies on a synthetic medium. Proc. Soc. exp. Biol. Med. 73, 1.

Yanagimachi, R. \& Ghang, M. G. (1963) Sperm ascent through the oviduct of the hamster and rabbit in relation to the time of ovulation. $\mathcal{F}$. Reprod. Fert. 6, 413.

Zamboni, L. (1972) Fertilization in the mouse. Biology of mammalian fertilization and implantation, Ch. 8. Eds. K. S. Moghissi and E. S. E. Hafez. G. G. Thomas, Springfield, Illinois. 